\title{
Seasonal variability of picoplankton in the Northern South China Sea at the SEATS station
}

\author{
Hongbin Liu ${ }^{\mathrm{a}, *}$, Jeng Chang ${ }^{\mathrm{b}}$, C.-M. Tseng ${ }^{\mathrm{c}}$, L.-S. Wen ${ }^{\mathrm{c}}$, K.K. Liu ${ }^{\mathrm{d}}$ \\ a Atmosphere, Marine and Coastal Environment (AMCE) Program, and Department of Biology, \\ Hong Kong University of Science and Technology, Clear Water Bay, Hong Kong, China \\ ${ }^{\mathrm{b}}$ Institute of Marine Environmental Chemistry and Ecology, and Institute of Marine Biology, National Taiwan Ocean University, \\ Keelung 202-24, Taiwan, ROC \\ ${ }^{\mathrm{c}}$ Institute of Oceanography, National Taiwan University, P.O. Box 23-13, Taipei 106, Taiwan \\ ${ }^{\mathrm{d}}$ Institute of Hydrological Sciences, National Central University, Jungli, Taiwan 320, ROC
}

Received in revised form 10 April 2006; accepted 14 May 2007

Available online 6 July 2007

\begin{abstract}
Flow cytometric analysis of picoplankton from the Southeast Asia Time-series Station (SEATS) in the South China Sea was performed for samples collected every 1-4 months during October 2001 to September 2002 (six cruises) and between November 2004 and December 2005 (four cruises). Prochlorococcus was the most abundant autotrophic picoplankton with the maximum abundance occurring in summer. Synechococcus and picoeukaryotes were 1 or 2 orders of magnitude less abundant during most of the year, but showed a much larger seasonal variation, with maximum abundance occurring in winter to early spring. The winter peak of Synechococcus and picoeukaryotes coincided with the deepening of the mixedlayer depth caused by surface cooling and the strong NE monsoon winds. Maximum bacterial biomass was observed in spring, and generally followed the winter peak of Synechococcus and picoeukaryotes with a time lag. Prochlorococcus contributed up to $80 \%$ of the total autotrophic biomass during summer, but Synechococcus and picoeukaryotes accounted for $60-80 \%$ of the total autotrophic biomass in winter. Bacterial biomass was less than the autotrophic biomass and the two were only weakly correlated. The interannual variability in the structure and composition of the picoplankton community may be related to the El Niño-Southern Oscillation (ENSO) cycle. During an El Niño year (2001-2002), with higher sea-surface temperature, chlorophyll $a$ was lower and Prochlorococcus and bacterial biomass were higher. In contrast, the higher picoeukaryote biomass during winter was probably responsible for the higher chlorophyll $a$ during the La Niña year of 2004-2005.
\end{abstract}

(C) 2007 Elsevier Ltd. All rights reserved.

Keywords: Picoplankton; Community structure; Seasonal variation; South China Sea; Flow cytometry

\section{Introduction}

The picophytoplankton $(<2 \mu \mathrm{m})$, including the cyanobacteria Prochlorococcus and Synechococcus

*Corresponding author. Tel.: + 85223587341 ; fax: +85223359317 .

E-mail address: liuhb@ust.hk (H. Liu). and the small eukaryotic algae, contribute substantially to both phytoplankton biomass and production in marine ecosystems (Li et al., 1983; Campbell 
et al., 1994; Liu et al., 2004). Because their rapid growth rates are closely matched by mortality losses due to grazing by microzooplankton, they play an important role in nutrient regeneration and cycling in the ocean. Because of its indisputable importance in marine primary production and biogeochemical cycling of carbon and nutrients, the dynamics of picoplankton, and its control mechanisms have been widely studied in various types of aquatic ecosystems in the last two decades. However, there is no report on the seasonal and interannual variation of picoplankton community structure in the South China Sea (SCS), the world's second largest marginal sea.

The SCS is a semi-enclosed basin with extensive continental shelves on the west and south sides and a deep basin over $3000 \mathrm{~m}$ deep. Several large rivers, including the Mekong River and the Pearl River, discharge to it. Climatic variations in the atmosphere and in the upper ocean of the SCS are primarily controlled by the East Asian monsoon, which follows closely the climatic variations in the equatorial central Pacific (Shaw and Chao, 1994). In addition, SCS is also subject to frequent passage of typhoons, and strong internal waves (Liu A.K. et al., 1998). All of these physical disturbances could influence water-column stability and the magnitude of vertical mixing in different time and spatial scales. This would in turn affect the upward flux of inorganic nutrients from deep water to the surface, and sequential biological processes in the upper water column. Therefore, SCS is a very good site to monitor the response of the oceanic ecosystem to climate change during various time scales, from episodic events to seasonal, interannual, and decadal. Based on the above consensus, scientists in Taiwan (Republic of China) established the Southeast Asia Time-series Station (SEATS) in the SCS in 1999. The primary station is located at $18^{\circ} \mathrm{N}$, $116^{\circ} \mathrm{E}$, about $700 \mathrm{~km}$ southwest of Taiwan (see map in Wong et al., 2007a). In this paper, we report flow cytometric analysis of picoplankton from the SEATS site and the elucidation of the seasonal and interannual variability in the structure and composition of the picoplankton community.

\section{Materials and methods}

Samples were collected at the SEATS station $\left(18^{\circ} \mathrm{N}, 116^{\circ} \mathrm{E}\right)$ in the SCS on six cruises between October 2001 and September 2002, and again on four cruises between November 2004 and July 2005.
Seawater was collected from eight depths within the upper $150 \mathrm{~m}$ of the water column using Go-Flo or Niskin bottles attached to a CTD rosette system; sub-samples $(2 \mathrm{ml})$ were preserved with paraformaldehyde $(0.2 \%$ final concentration), quick frozen, and stored in liquid nitrogen until analysis.

An LSR flow cytometer (Becton Dickinson) equipped with a 488-nm laser was used to enumerate the picoplankton. Forward and side light scatters (FSC and SSC) and green $(515-545 \mathrm{~nm})$, orange $(564-606 \mathrm{~nm})$, and red $(>650 \mathrm{~nm})$ fluorescence were collected, saved, and analyzed with CYTOWIN software (Vaulot, 1989). All signals were normalized to that of the $1-\mu \mathrm{m}$ Fluoresbrite YG beads (Polysciences, Warrington, PA) that were added to each sample. Three major groups of picophytoplankton, Prochlocococcus, Synechococcus and picoeukaryotes, were distinguished based on their autofluorescence properties. Heterotrophic bacteria were enumerated in a separate sub-sample stained with the nucleic acid stain SYBR Green I (Molecular Probes) (Marie et al., 1997).

Sizes of each picoplankton category were estimated by counting cell numbers that pass through $0.4,0.6,0.8,1.0,2.0$, and $3.0-\mu \mathrm{m}$ polycarbonate membrane filters (Zubkov et al., 1998). These measurements were deployed only during July and September 2002 cruises and the resulting size estimates were applied to all cruises. For bacteria, Prochlorococcus and Synechococcus cell volumes were converted to carbon using a conversion factor of $280 \mathrm{fg} \mathrm{C} \mathrm{m}^{-3}$ (Heldal et al., 2003). Because the size fractionation method we employed in this study is not suitable for picoeukaryotes due to the breaking of delicate cells during the filtration, we used a carbon content of $1500 \mathrm{fg} \mathrm{Cell}^{-1}$ determined by Zubkov et al. (1998).

Hydrographic, nutrients and chlorophyll $a(\operatorname{chl} a)$ data were provided by the SEATS core program (see Tseng et al., 2005). The mixed-layer depth (MLD) during each cruise was estimated as the depth above which the density gradient was 0.1 unit $\mathrm{m}^{-1}$. Chl $a$ was measured by the fluorometric method (Strickland and Parsons, 1984) using $\mathrm{GF} / \mathrm{F}$ filters.

\section{Results}

\subsection{SST, MLD and chlorophyll a concentrations}

Details of physical and chemical characteristics at the SEATS site are reported elsewhere (Tseng et al., 
2005, 2007; Wong et al., 2007b). We present here a few parameters that are most relevant to our study in the temporal distribution of picoplankton (Fig. 1). The sea-surface temperature (SST) varied between $>30{ }^{\circ} \mathrm{C}$ in July 2001 and $23^{\circ} \mathrm{C}$ in January 2005. The two sampling years showed a similar seasonal pattern, but the SST in 2001-2002 appeared to be higher than that in 2004-2005. There were large variations in the MLD throughout each year, and the range of the variation was very similar for both years. Shallow MLDs between 10 and $30 \mathrm{~m}$ were observed between spring to fall, but deep MLDs of $>90 \mathrm{~m}$ occurred in winter. The
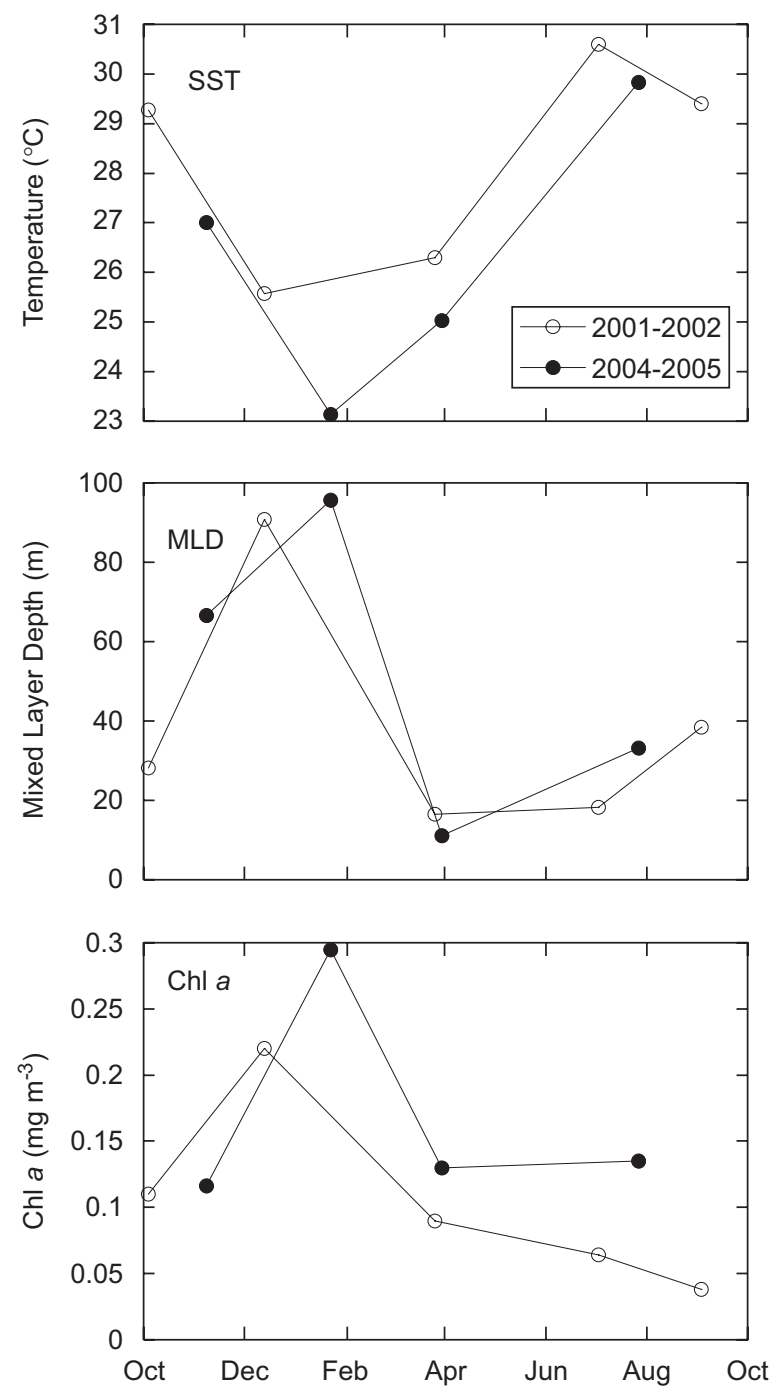

Fig. 1. Sea-surface temperature (SST), mixed-layer depth (MLD) and chlorophyll $a$ concentration in the surface water of SEATS during 2001-2002 and 2004-2005. surface chl $a$ concentrations showed a peak during winter, in accordance with low SST and deep MLD.

\subsection{Picoplankton abundance}

Prochlorococcus was the dominant picophytoplankton, in terms of cell number, at the SEATS site. Abundance in the surface mixed layer reached $1.5-2.8 \times 10^{5}$ cells ml $^{-1}$. Abundance of Synechococcus and picoeukaryotes were more than one order of magnitude lower, except in the winter to early spring period, in which Synechococcus abundance as high as $1 \times 10^{5}$ cells ml $^{-1}$ was observed in the December 2001 and January 2004 cruises. There are striking similarities between the 2 years in the vertical distributions and seasonal variations of picoplankton (Fig. 2). During both winters, the abundance of Prochlorococcus occurred evenly in the surface water from 0 to about $50 \mathrm{~m}$, and then decreased gradually with depth. In spring and summer, the highest Prochlorococcus abundances were usually found in sub-surface waters around $50 \mathrm{~m}$. A summer abundance peak was observed in both years, and a winter peak was also evident in the winter of 2001-2002, but not in the winter of 2004-2005, probably due to the lower temperature in the surface mixed layer. Overall, Prochlorococcus was more abundant in 2001-2001 than in 2004-2005.

In general, Synechococcus was most abundant in the surface mixed layer and only very few cells were counted below $100 \mathrm{~m}$. They possessed the strongest seasonal variations with a "bloom" occurring in winter to early spring. During most of the year, the maximum abundance of Synechococcus was $<10^{4}$ cells ml ${ }^{-1}$, but abundances of $10^{5}$ and $8 \times 10^{4}$ cells ml ${ }^{-1}$ were recorded in December 2001 and January 2004, respectively.

The abundance of picoeukaryotes ranged between 500 and 15,000 cells ml $^{-1}$ (the maximum abundance occurred at $60 \mathrm{~m}$ in March 2005) in the surface mixed layer with a strong deep maximum at 60-80 $\mathrm{m}$, except in winter, in which the maximum abundance occurred at the surface. Maximum abundance was observed in winter and spring, and the abundance in 2004-2005 was significantly higher than that in 2001-2002.

The abundance of heterotrophic bacteria ranged from $6.2 \times 10^{5}$ to $1.2 \times 10^{6}$ cells ml $^{-1}$ (March 2002) in the surface water and $2.5-3.1 \times 10^{5}$ cells ml $^{-1}$ at $150 \mathrm{~m}$ depth. The seasonal distribution pattern of heterotrophic bacteria appears to closely follow the 

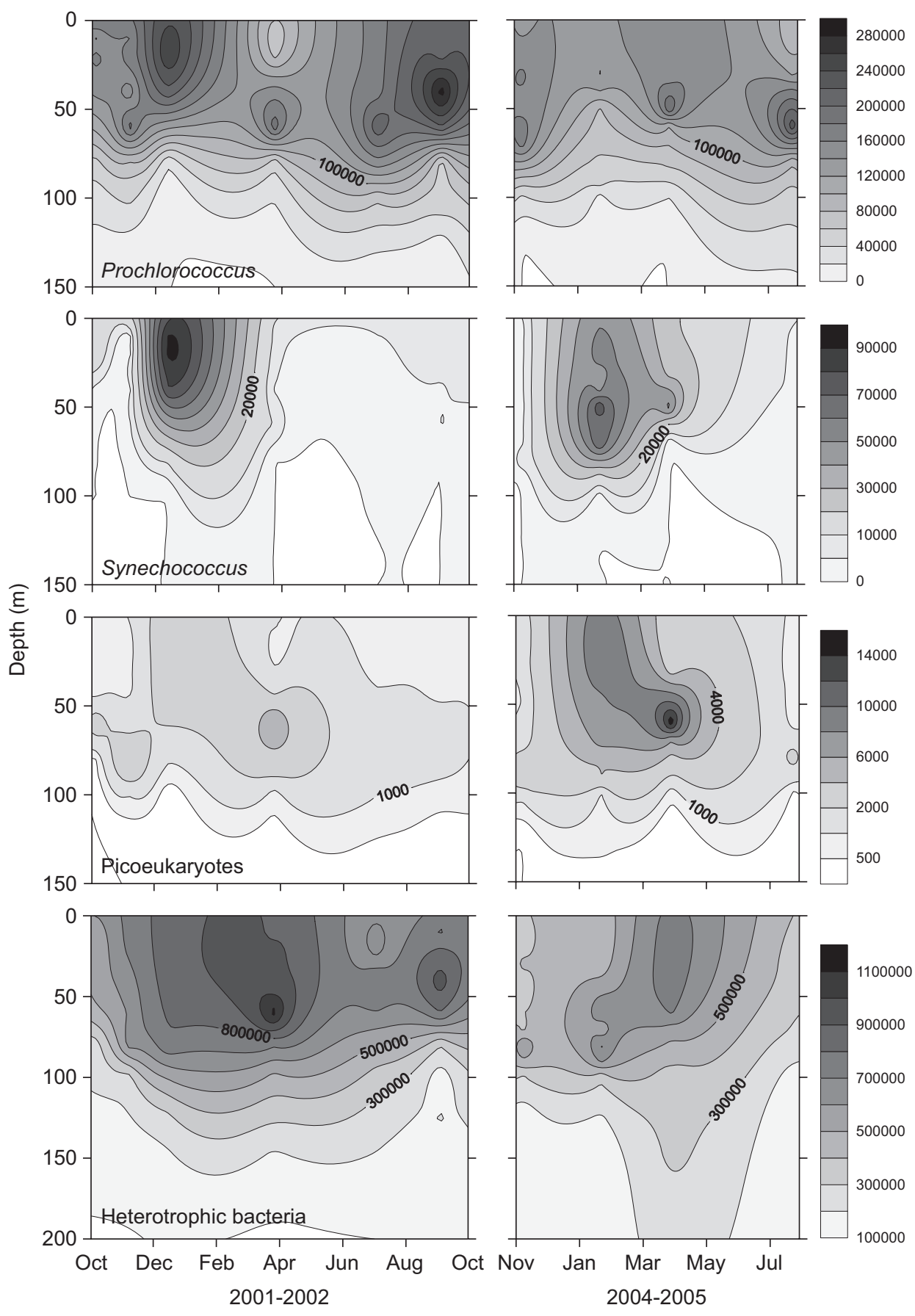

Fig. 2. From the top: Contour plots for Prochlorococcus, Synechococcus, picoeukaryotes, and heterotrophic bacterial abundance $\left(\right.$ cell $\mathrm{ml}^{-1}$ ) at SEATS station during 2001-2002 and 2004-2005.

seasonal variation in autotrophic picoplankton. Like Prochlorococcus, heterotrophic bacteria abundance was higher in 2001-2002 than in 2004-2005.

The integrated abundance of Prochlorococcus in the upper $150 \mathrm{~m}$ varied less than one fold each year, with a high abundance occurring in summer and a low abundance in late winter to early spring (Fig. 3(A)). In contrast, there was an $>10$-fold increase in Synechococcus abundance in winter compared to the abundance during the rest time 
(A)

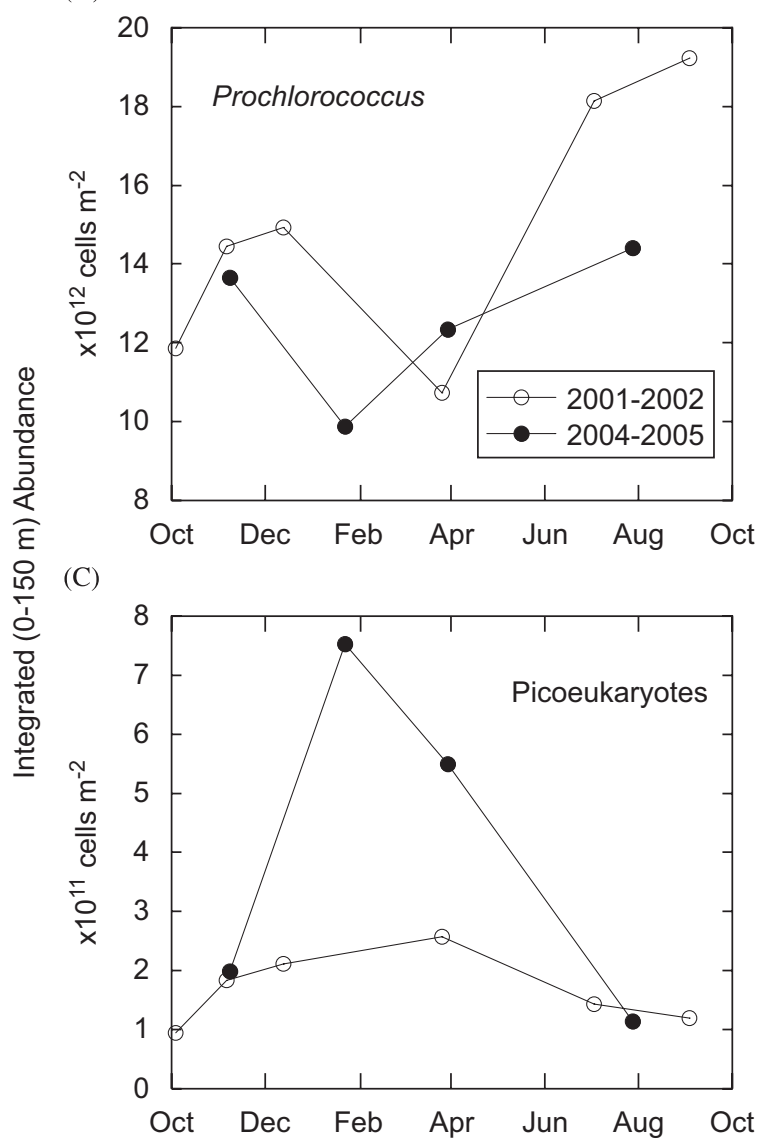

(B)

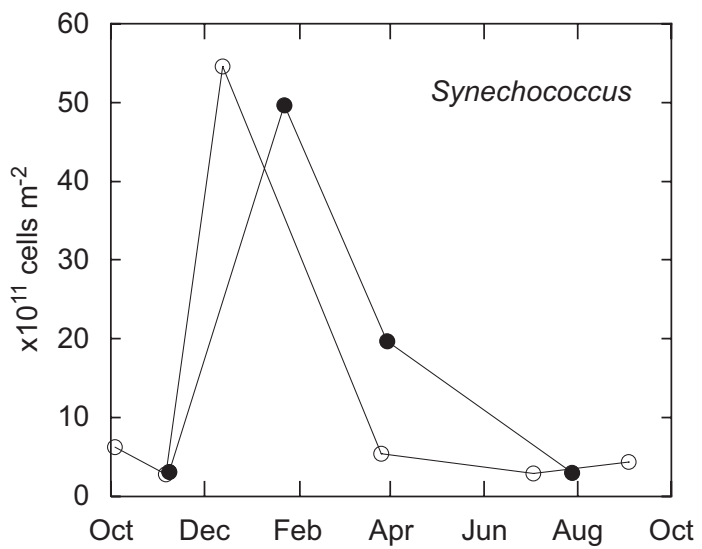

(D)

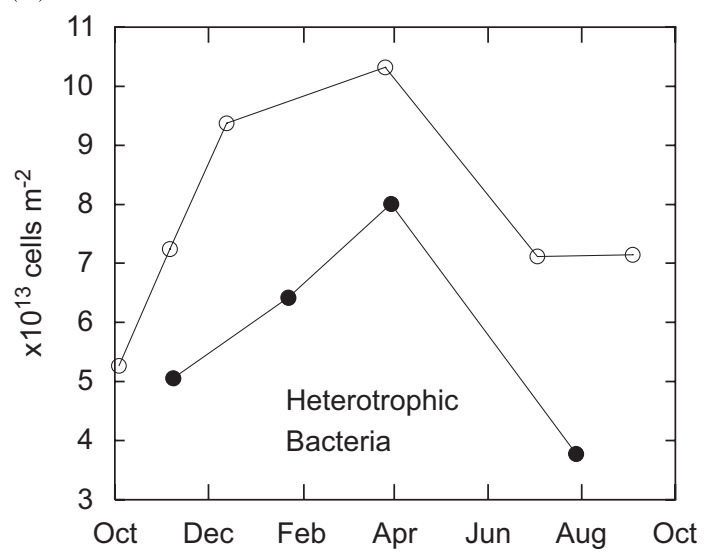

Fig. 3. Integrated $(0-150 \mathrm{~m})$ abundance of Prochlorococcus, Synechococcus, picoeukaryotes, and heterotrophic bacteria at the SEATS site from October 2001 to September 2002 and from November 2004 to July 2005.

of the year (Fig. 3(B)). The abundance of picoeukaryotes increased slightly in the spring of 2002, but a much larger increase was observed in January and March 2005 (Fig. 3(C)). Bacterial biomass was high in spring following the peak of Synechococcus and picoeukaryotes (2005 only) (Fig. 3(D)).

\subsection{Cellular fluorescence}

Cellular chlorophyll fluorescence, which is an index of cellular chl $a$, increased with depth for all photosynthetic picoplankton. The vertical profiles of chlorophyll fluorescence for the three types of picophytoplankton all have relatively constant low fluorescence in the surface mixed layer and a sharp increase below that layer (Fig. 4). The vertical fluorescence distribution pattern for Prochlorococcus and picoeukaryotes were similar, with a dramatic increase in fluorescence occurring between 50 and $100 \mathrm{~m}$. The fluorescence of Synechococcus reached a maximum between 60 and $100 \mathrm{~m}$, and then decreased for cells in the deep layer. However, since there were very few cells below $100 \mathrm{~m}$, those cells were likely not in a physiologically healthy condition. Seasonally, all the three picophytoplankton groups in the surface mixed layer showed higher cellular fluorescence in winter and spring and low fluorescence in summer, reflecting higher average irradiance in the mixed layer resulting from high light and a shallow mixed layer during summer months. The lowest chlorophyll fluorescence occurred in the surface water in summer 2002 (Fig. 5). There was a 5-fold seasonal variation in the cellular chlorophyll fluorescence of Prochlorococcus in the upper mixed layer in 2001-2002, with the maximal cellular fluorescence occurring in December 2001. A much smaller seasonal variation in Prochlorococcus chlorophyll fluorescence ( $<2$ fold) was observed in 2004-2005. Highest Synechococcus cellular chlorophyll fluorescence occurred in January 2005, 

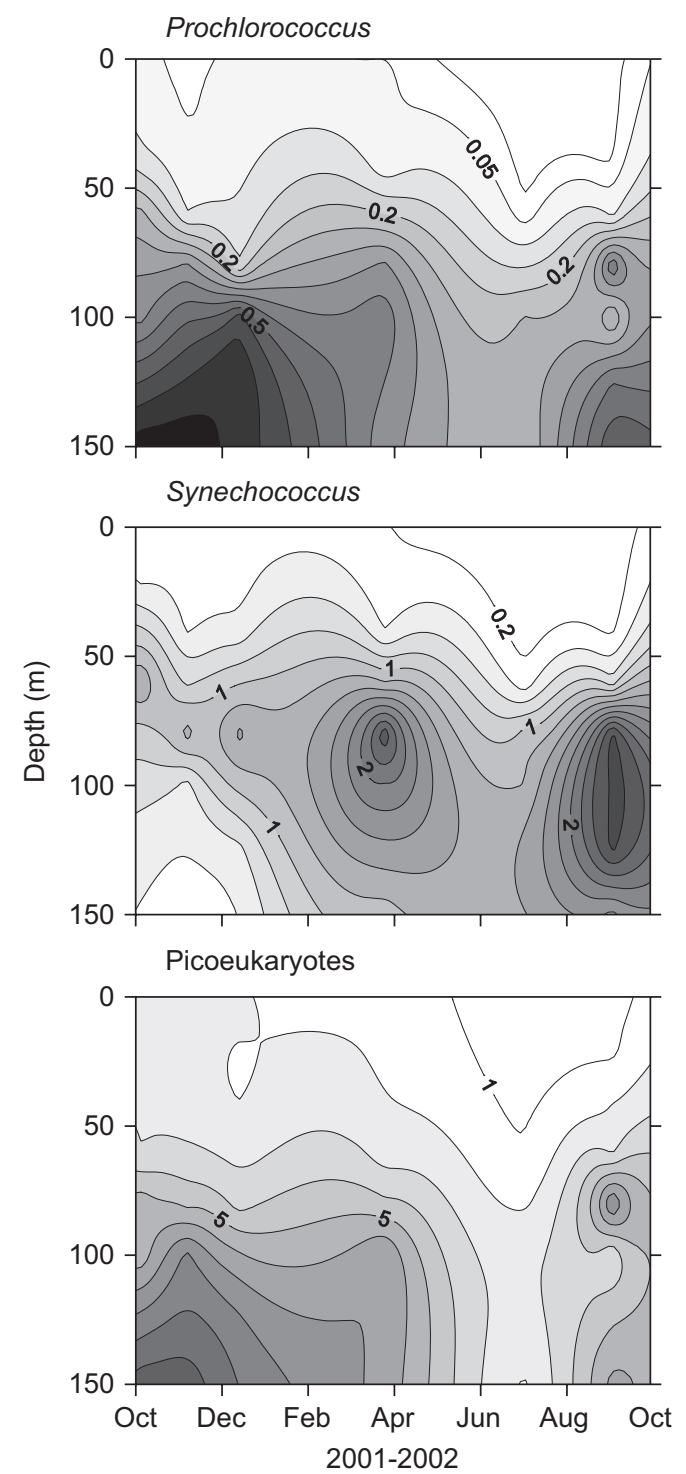
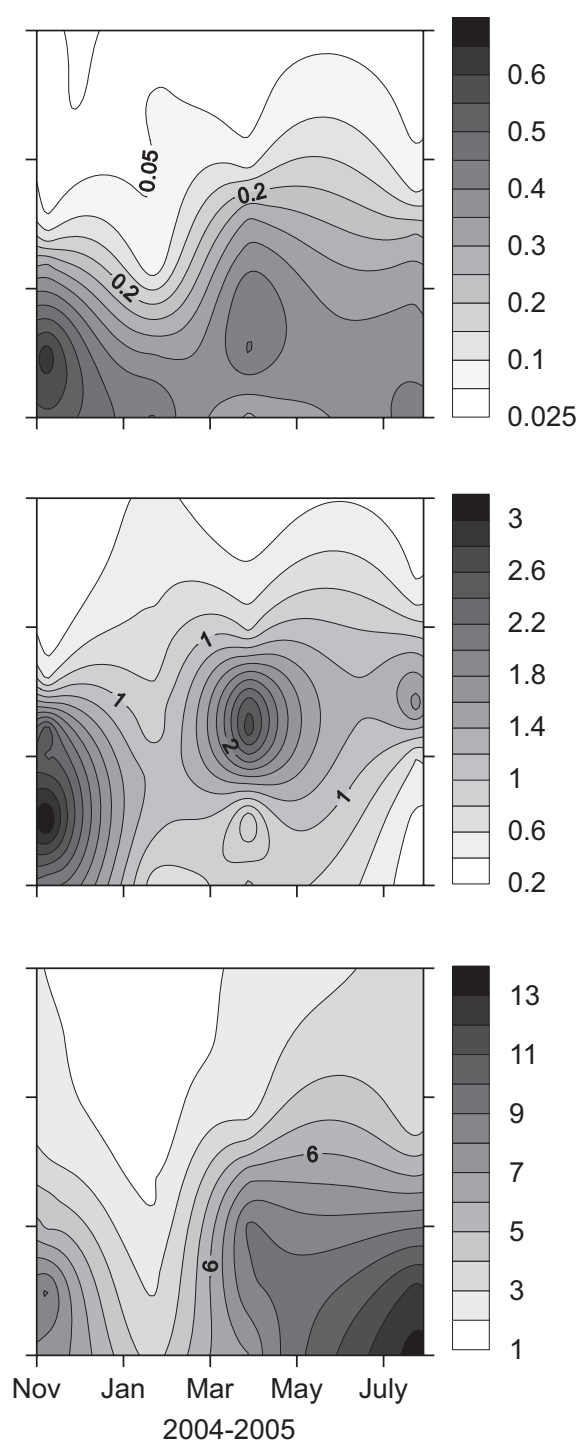

Fig. 4. Contours of relative cellular chlorophyll fluorescence for Prochlorococcus, Synechococcus and picoeukaryotes at SEATS station. All chlorophyll fluorescence was normalized to 1- $\mu \mathrm{m}$ Fluoresbrite YG beads (Polysciences).

corresponding to its biomass maximum. In contrast, the cellular chlorophyll fluorescence of Synechococcus at its December 2001 peak abundance was not apparently enhanced. Similar to that of Prochlorococcus, seasonal variation of Synechococcus chlorophyll fluorescence was greater in 2001-2002 (4.7 fold) than in 2004-2005 (2.3 fold). Completely different patterns were observed for cellular chlorophyll fluorescence of picoeukaryote in the surface mixed layer during two sampling periods. A cellular fluorescence maximum was observed for picoeukaryotes throughout the upper $150 \mathrm{~m}$ water column in July 2005, corresponding to a fluorescence minimum in 2002.

The highest vertical cellular fluorescence variation for Prochlorococcus, Synechococcus and picoeukaryotes all occurred in late summer to early fall (Figs. 4 and 6), namely September 2002 and November 2004, and the lowest occurred in winter to spring months. Prochlorococcus displayed the highest increase of cellular chlorophyll fluorescence between the low-fluorescence surface cells and the high-fluorescence cells in the bottom of the euphotic zone. The difference is $6-28$ fold, with the biggest 

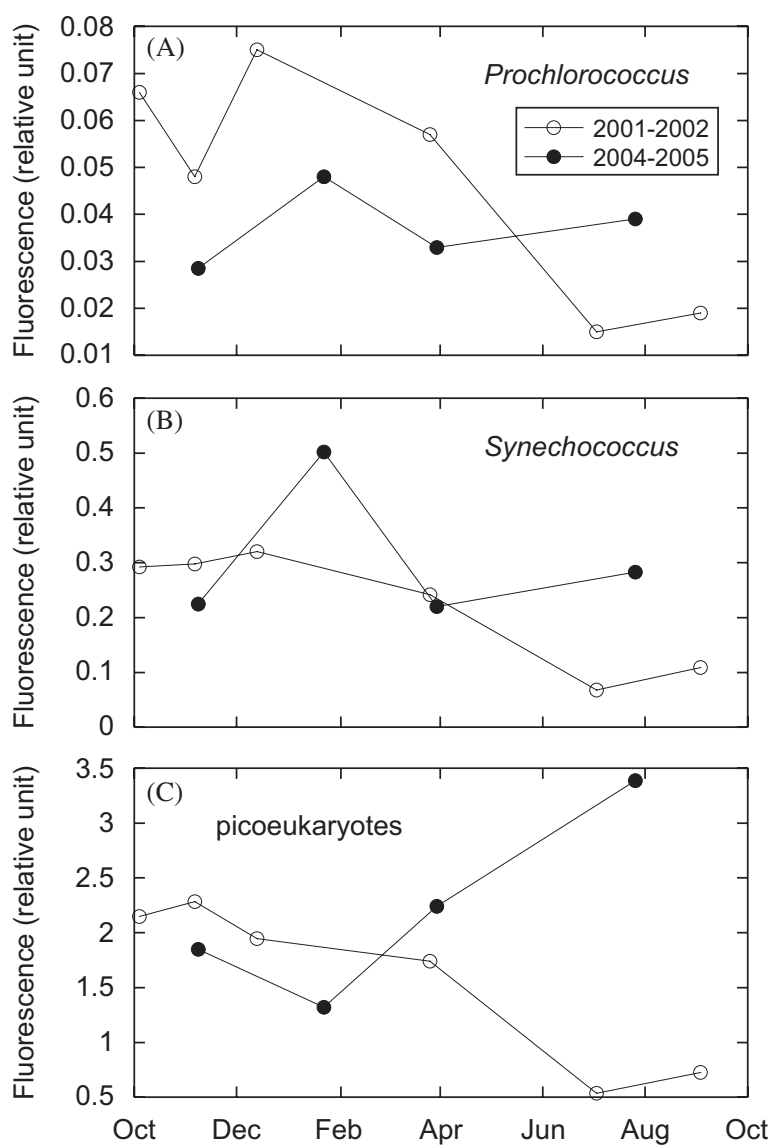

Fig. 5. Seasonal variations in cellular fluorescence of (A) Prochlorococcus, (B) Synechococcus, and (C) picoeukaryotes in the upper mixed layer (data from $20 \mathrm{~m}$ were used to represent the upper mixed layer).

increase in September 2002, coincident with one of the highest abundances that occurred at $40 \mathrm{~m}$ (Figs. 2 and 6). Synechococcus and picoeukaryotes showed fluorescence increases of 2-24 fold and 3-11 fold, respectively, between the cells in the surface mixed layer and sub-surface maximum.

\subsection{Biomass estimates}

Results from the size fractionation method revealed that the size of the heterotrophic bacteria did not change significantly from the surface to $100 \mathrm{~m}$, ranging from 0.35 to $0.48 \mu \mathrm{m}$ in diameter (Fig. 7). We used an overall average of 11 $(10.6 \pm 3.0) \mathrm{fg} \mathrm{C}$ cell $^{-1}$ based on a carbon to volume

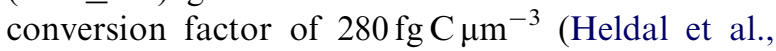
2003). In contrast, the size of Prochlorococcus and Synechococcus in the deep euphotic layers was significantly larger than those in the upper euphotic

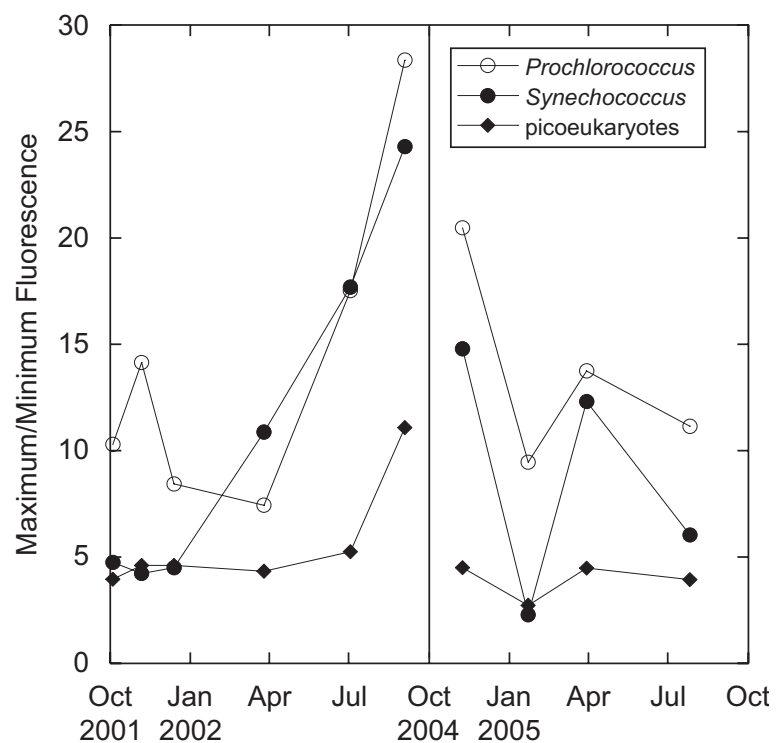

Fig. 6. Seasonal variation in the cellular fluorescence increase between the low-fluorescence cells in surface waters and the brighter-fluorescence cells in deep waters for Prochlorococcus, Synechococcus, and picoeukaryotes.

layers (Fig. 7). Therefore we calculated their cellular carbon content separately using $60 \mathrm{~m}$ as the bottom boundary of the upper euphotic layer (Table 1). For Prochlorococcus and Synechococcus in the upper euphotic layer, the estimated cellular carbon contents were $24 \pm 4$ and $67 \pm 32 \mathrm{fg} \mathrm{C}$ cell $^{-1}$, respectively. For those living in the deep euphotic layer, cellular carbon contents were much higher $(62 \pm 29$ and $157 \pm 68 \mathrm{fg} \mathrm{Cell}^{-1}$ for Prochlorococcus and Synechococcus, respectively).

High autotrophic biomass occurred each winter (Fig. 8(A)). Among three autotrophic picoplankton, Prochlorococcus dominated autotrophic carbon biomass during most of the year, and contributed $70-80 \%$ of the autotrophic picoplanktonic biomass in summer and fall months (Fig. 8(B)). The seasonal patterns of the contribution of Synechococcus and picoeukaryotes to total autotrophic picoplankton carbon are opposite to that of Prochlorococcus. Synechococcus was not a large component of the biomass, except in December 2001 (38\% of total) and January 2005 (23\%) when Synechococcus "bloomed"; during the Synechococcus "bloom", the contribution of Prochlorococcus dropped to $39 \%$ and $17 \%$, respectively. The contribution of picoeukaryotes during the first sampling period ranged from 17\% (September 2002) to 40\% (March 2002), and increased during the second sampling 


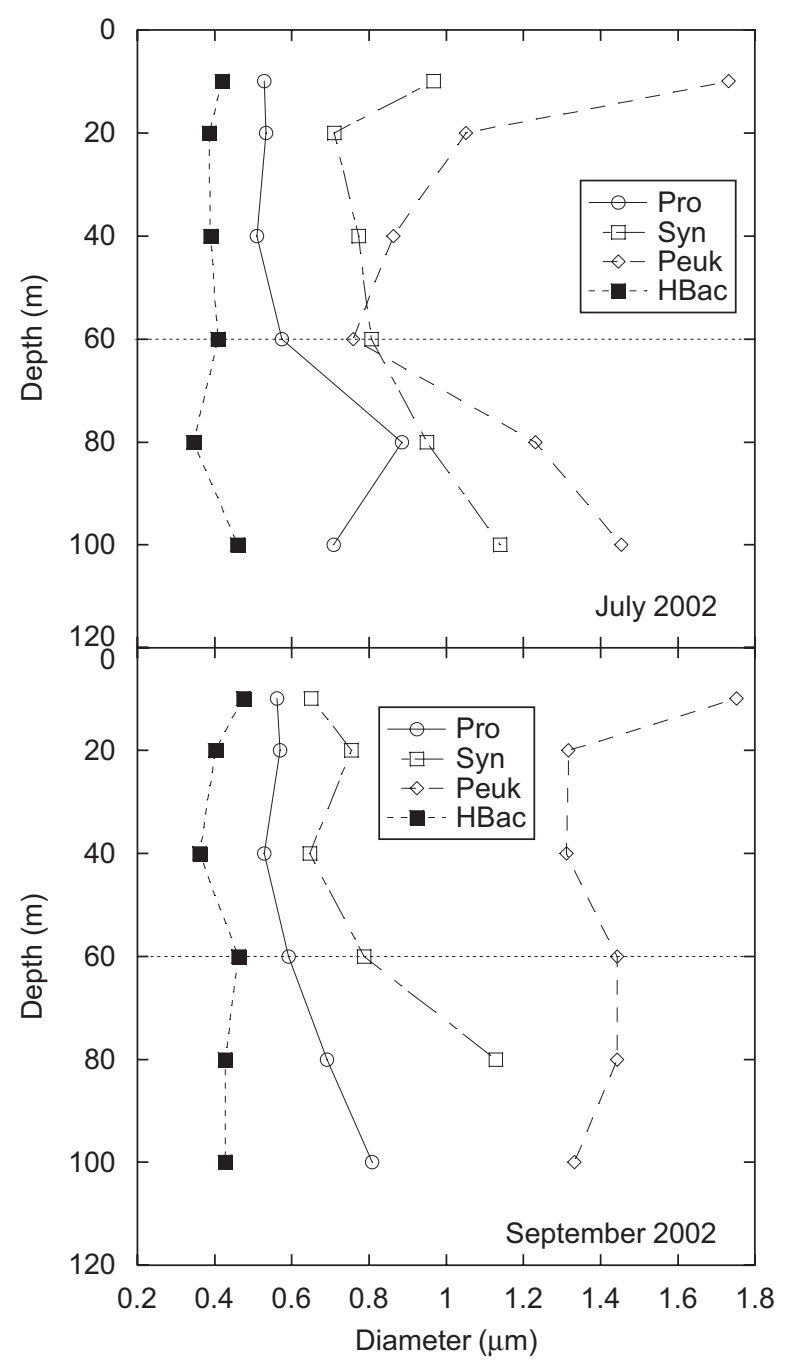

Fig. 7. Vertical profiles of the equivalent spherical diameter (ESD) of each component of the microbial community at the SEATS site, estimated by the serial filtering approach (see Materials and Methods for details). Dotted line indicates the depth to separate the upper and lower euphotic layers used to calculate the sizes of Prochlorococcus and Synechococcus separately in Table 1.

period to between $18 \%$ (July 2005) and $61 \%$ (January 2005).

Bacterial biomass in the upper $150 \mathrm{~m}$ water column followed the autotrophic biomass, but there appeared to be a time lag of 1-2 months (Fig. 9(A)), which may explain the relatively low correlation coefficient between the two (Fig. 9(B)). In general, bacterial biomass in the upper $150 \mathrm{~m}$ was less than the biomass of autotrophic picoplankton, with one exception in March 2002. The ratio of bacterial biomass to picophytoplankton biomass was higher
Table 1

Estimated cell size (ESD) and cellular carbon content for heterotrophic bacteria, Prochlorococcus spp., Synechococcus spp., and picoeukaryotes

\begin{tabular}{lll}
\hline & Diameter $(\mu \mathrm{m})$ & Carbon $\left(\mathrm{fg} \mathrm{Cell}^{-1}\right)$ \\
\hline $\begin{array}{l}\text { Heterotrophic bacteria } \\
\text { Prochlorococcus }\end{array}$ & $0.41 \pm 0.04$ & $11 \pm 3$ \\
Above 60 m & $0.55 \pm 0.03$ & $24 \pm 4$ \\
Below 60 m & $0.73 \pm 0.12$ & $62 \pm 29$ \\
Synechococcus & & \\
Above 60 m & $0.76 \pm 0.11$ & $67 \pm 32$ \\
Below 60 m & $1.01 \pm 0.16$ & $157 \pm 68$ \\
Picoeukaryotes & $1.31 \pm 0.30$ & Not estimated \\
\hline
\end{tabular}

Data are the mean \pm standard deviation of estimates made from six depths in the upper $100 \mathrm{~m}$ water column in July and September 2002. See text and Fig. 7 for details.

in 2001-2002 $(0.81 \pm 0.17$, mean \pm stand deviation, $n=6)$ than in 2004-2005 $(0.53 \pm 0.16, n=4)$.

\section{Discussion}

\subsection{Cell size and cellular carbon content}

Our estimated cell volumes for bacteria and cyanobacteria are comparable with other estimates. For example, our estimated Prochlorococcus and Synechococcus cell diameters are in good agreement with reported sizes of 0.54 and $0.73 \mu \mathrm{m}$, respectively, for samples collected from the oligotrophic western equatorial Pacific (Blanchot et al., 2001). Our estimates of cell sizes for Prochlorococcus and Synechococcus are slightly smaller than those in the Arabian Sea reported by Shalapyonok et al. (2001). Using an empirical relationship obtained between FLS and Coulter size on marine phytoplankton cultures, they estimated average values of $0.61-0.64$ and $0.79-0.87 \mu \mathrm{m}$ for Prochlorococcus in the surface mixed layer and below the mixed layer, respectively. For Synechococcus, their estimates were $0.91-0.95$ and $0.98-1.14 \mu \mathrm{m}$, respectively. Using the same method, DuRand et al. (2001) estimated cell diameters of $0.68 \mu \mathrm{m}$ (range 0.53-0.94) and $0.87 \mu \mathrm{m}$ (range $0.74-1.22$ ), respectively, for Prochlorococcus and Synechococcus in the Sargasso Sea, which is close to our estimates. There is no study on the effect of fixatives on picoplankton cell size. The only study shows that fixatives and deep freezing have no effect on FALS of bacteria and picoeukaryotes (Troussellier et al., 1995).

There is significant uncertainty over carbon contents of prokaryotic picoplankton, stemming 

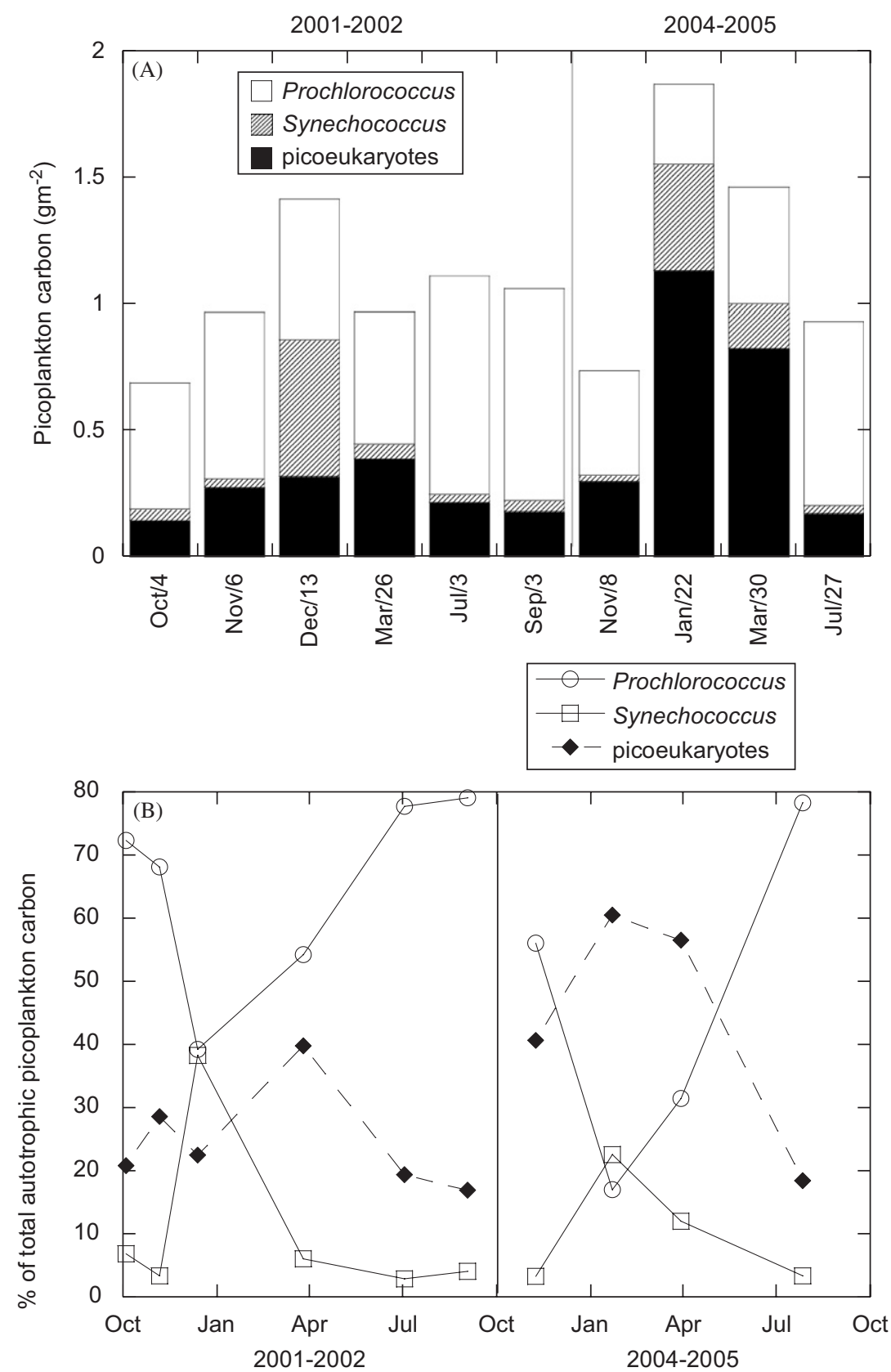

Fig. 8. (A) Estimated total 0-150 m integrated autotrophic picoplankton carbon biomass partitioned to Prochlorococcus, Synechococcus, and picoeukaryotes. (B) Percentage contribution of Prochlorococcus, Synechococcus, and picoeukaryotes to total autotrophic picoplankton biomass.

from uncertainties in both size and volume to carbon conversion factors. We chose to adopt a carbon density factor of $280 \mathrm{fg} \mathrm{C} \mathrm{m}^{-3}$, which is obtained from an equatorial Pacific strain of Prochlorococcus using X-ray microanalysis techniques (Heldal et al., 2003). This factor is in good agreement with the $235 \mathrm{fgC}^{-3}$ reported for
Synechococcus using a CHN analyzer (Shalapyonok et al., 2001). Our estimated carbon contents for Prochlorococcus and Synechococcus were lower than most of other estimates. For Prochlorococcus, our estimates for the upper euphotic layer $\left(24 \mathrm{fg} \mathrm{Cell}^{-1}\right)$ were lower than the range of 46-61 $\mathrm{fg} \mathrm{C}^{-1}$ reported by Bertilsson et al. 

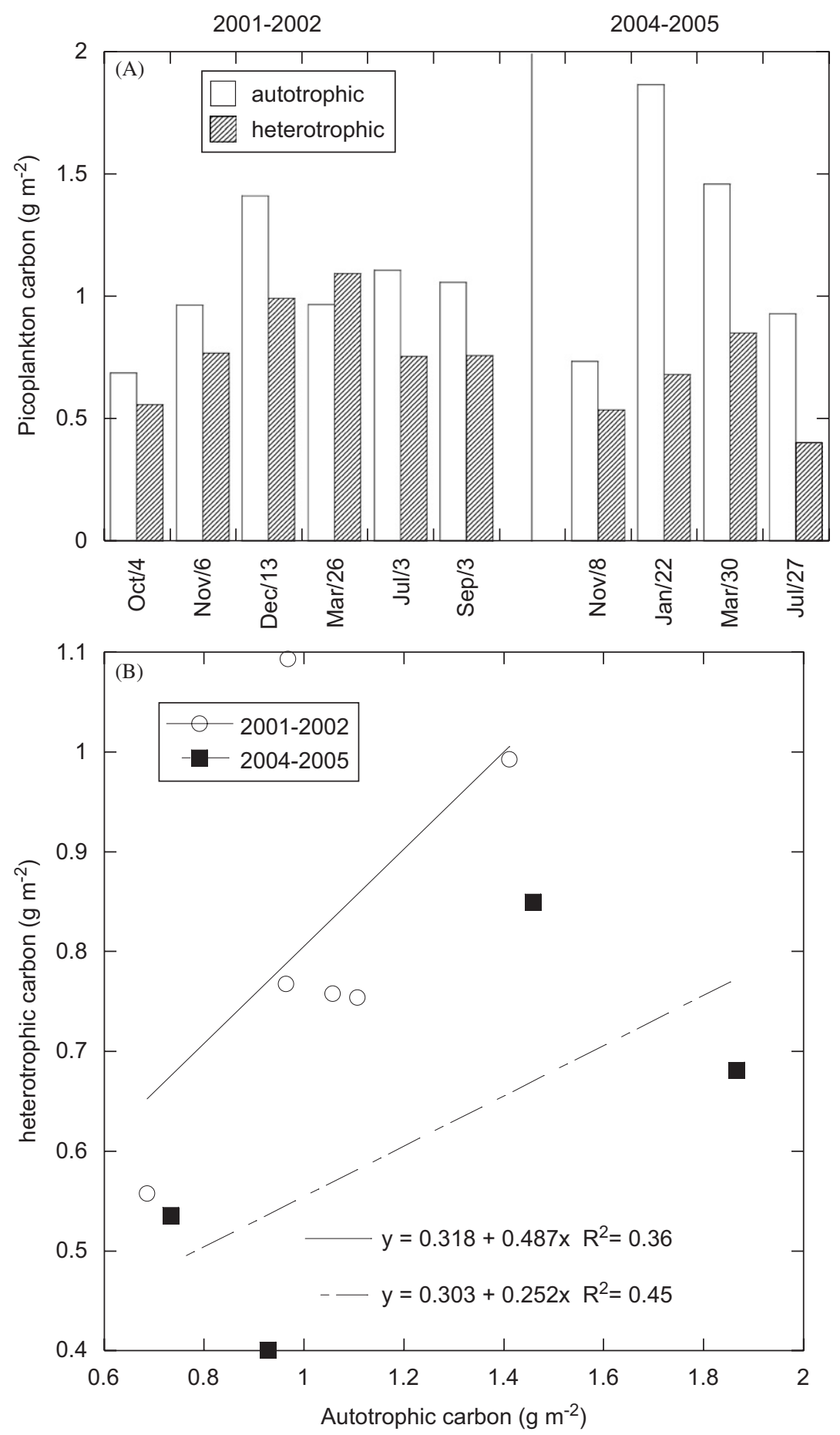

Fig. 9. Estimated total $0-150 \mathrm{~m}$ integrated autotrophic and heterotrophic picoplankton carbon biomass at SEATS station during 2001-2002 and 2004-2005 (A), and the correlation between auto- and heterotrophic carbon (B).

(2003) and $49 \mathrm{fg} \mathrm{C} \mathrm{Cell}^{-1}$ as estimated by Cailliau et al. (1996), as well as $32 \mathrm{fg} \mathrm{C} \mathrm{cell}^{-1}$ by Shalapyonok et al. (2001) and Zubkov et al. (1998), but in agreement with the $24 \mathrm{fgCcell}^{-1}$ reported by
Chavez et al. (1991) and $27 \mathrm{fg} \mathrm{C}$ cell $^{-1}$ reported by Claustre et al. (2002). The main reason that our estimates of Prochlorococcus and Synechococcus carbon contents are on the low end of all the 
estimates is that we have adopted newly measured values, but we believe it is a more accurate carbon density factor that is lower than most previously used values.

Our finding that the cyanobacteria cells inhabiting the top layer are smaller than those inhabiting the deeper layer is also in agreement with the findings of Shalapyonok et al. (2001). Some of these differences have been attributed to succession between dominance by the two ecotypes of Prochlorococcus, which are adapted to grow at different light intensities and have different sizes (e.g., Zubkov et al., 1998), but we have not observed the co-occurrence of different Prochlorococcus in flow cytometric analysis. The smaller cyanobacteria cell size in the upper waters may be related to nutrient depletion, as well as photoacclimation (i.e. reduction of the pigment content at high light levels). In laboratory batch cultures, Bricaud et al. (1999) have shown that cell size of Prochlorococcus strain MED4 grown under high light is smaller than the size of cells grown under low light.

Our estimates of picoeukaryote size $(1.31 \pm 0.30 \mu \mathrm{m})$ are much smaller than other estimates. Estimates of picoeukaryotes equivalent spherical diameter (ESD) based on other methods centered around $2 \mu \mathrm{m}$, e.g., 1.93-2.07 $\mu \mathrm{m}$ in equatorial Pacific (Blanchot et al., 2001) and $2.28 \mu \mathrm{m}$ in sub-tropical Pacific (Campbell et al., 1994). Although Zubkov et al. (1998) suggested that the filtration method is not suitable for picoeukaryotic cells because of the breakage of fragile cells during the filtering procedure, without accompanying independent measurements to use as a comparison, we are not able to judge whether our estimate is invalid. Nevertheless, the observed vertical distribution of picoeukaryotic cell size is very similar to the pattern reported by Shalapyonok et al. (2001), which showed that the picoeukaryotes in the surface water were larger than those in the sub-surface chlorophyll maximum in the Arabian Sea.

Our estimates of bacteria size and carbon content agree well with Ducklow et al.'s (2001) $0.4 \mu \mathrm{m}$ ESD, Garrison et al.'s (2000) $11 \mathrm{fg} \mathrm{C}$ cell $^{-1}$, and Fukuda et al.'s (1998) $10.6 \mathrm{fg} \mathrm{C}$ cell $^{-1}$.

DuRand et al. (2001) reported that there is a seasonal variation in the cell size of Prochlorococcus and Synechococcus, with diameter minima for both picoplankton groups occurring during the summer and maxima present in the spring of each year. If that phenomenon also applies to our study site, our estimated cell sizes for Prochlorococcus and
Synechococcus will be conservative because they were based on measurements done during summer.

\subsection{Seasonal variation in community structure}

The seasonal variations in picophytoplankton community structure we observed are similar to those in other sub-tropical regions of the ocean. In the North Atlantic at Station OFP, there was a 3-fold increase for integrated Prochlorococcus abundance in summer, a 5-fold increase for Synechococcus, and an approximately 2-fold increase for picoeukaryotes in winter (Olson et al., 1990). The same seasonal pattern was observed at the Bermuda Atlantic Time-series Study (BATS) station in the Sargasso Sea (DuRand et al., 2001). In the North Pacific at Hawaii Ocean Time-series (HOT) station ALOHA, Synechococcus and picoeukaryotes abundance in the upper $200 \mathrm{~m}$ in winter and early spring were about five times greater than they were in the rest of the year, but such peaks were not observed every year. The annual cycle in the 200-m-integrated Prochlorococcus abundance at station ALOHA is less clear, but a minimum was observed each winter (Campbell et al., 1997). Because of the predominance of Prochlorococcus at station ALOHA (Campbell et al., 1994), the maximum chl $a$ biomass and primary production occurred in summer or fall, coincident with the peak abundance of Prochlorococcus (Winn et al., 1995; Campbell et al., 1997). In contrast, the contribution of Synechococcus and picoeukaryotes to photosynthetic biomass at SEATS site is much higher as compared to station ALOHA. Synechococcus and picoeukaryotes "bloom" at SEATS site during winter (Figs. 2 and 3), resulting in the winter peak of chl $a$ and primary production (Liu et al., 2001; Tseng et al., 2005). Therefore, despite the similar seasonal variation patterns of the MLD at stations SEATS and ALOHA, the two sites display very different seasonal cycles in total chl $a$ and primary production.

Despite the uncertainties in converting the abundance to carbon biomass and the lack of direct counts of microplankton, it is clear that picophytoplankton accounted for the overwhelming majority of the photosynthetic biomass in the oligotrophic SCS as inferred from the low chl $a$ concentrations (Fig. 1). HPLC pigment analysis revealed that diatoms and dinoflagellates were insignificant minor components of the phytoplankton community (L.S. Wen, unpublished data). The fucoxanthin (an accessory 
pigment that is presented in diatoms and pelagophytes) to chl $a$ ratios in the upper $150 \mathrm{~m}$ of the water column at the SEATS site measured in October 2002 and September 2003 were all $<0.1$ (L.S. Wen, unpublished data, fucoxanthin:chl $a$ ratio for diatoms is normally $>1$, see Suzuki et al., 2002).

Since different carbon per cell conversion factors were used in different studies (see discussion in Section 4.1), it is not meaningful to compare directly our biomass estimates with other oceanic regions. Nevertheless, like the seasonal pattern in abundance, the seasonal patterns of the integrated picoplankton biomass and its composition at the SEATS site are somewhat different from the subtropical North Pacific Ocean at station ALOHA. Unlike the sub-tropical North Pacific, where Prochlorococcus biomass dominates photosynthetic biomass throughout the year, the contribution of Prochlorococcus to total picophytoplankton biomass varied greatly from $70 \%$ to $80 \%$ in summer/fall to $<40 \%$ during winter in SCS. Unlike the sub-tropical North Pacific, where the contribution of Synechococcus was a very small percentage of the total biomass, the contribution of Synechococcus in the SCS during winter "bloom" can be as high as $40 \%$.

The winter "bloom" of Synechococcus and picoeukaryotes occurred when a deepening of MLD, driven by a combination of surface cooling and wind mixing, made nutrients available. The nitrate concentrations in the surface mixed layer were $>0.1 \mu \mathrm{M}$ during both winters, which is about an order of magnitude higher than that during the rest of the year (data not shown, but see Tseng et al., 2005; Wong et al., 2007b). It is well known that Synechococcus can respond quickly to nitrate input (Glover et al., 1988). On the other hand, Prochlorococcus abundance and growth rates were found to be negatively correlated with both nitrate and phosphate concentrations (Liu H. et al., 1998; Partensky et al., 1999; Cavender-Bares et al., 2001). Recent studies have shown that cultures of Prochlorococcus cannot utilize nitrate for growth (Rippka et al., 2000; Moore et al., 2002), but they are able to take up organic nitrogen compounds (Zubkov et al., 2003).

\subsection{Seasonal variation in cell fluorescence}

Seasonal patterns in picoplankton cellular fluorescence appear to be related to both the physical dynamics and the succession of different species or ecotypes of picoplankton. DuRand et al. (2001) attributed observed seasonal fluorescence patterns at the BATS site to the depth of the nitracline, which showed a strong seasonal variation with nitrate concentrations $>0.1 \mu \mathrm{mol} \mathrm{kg}{ }^{-1}$ in the surface water during each winter. Unlike the BATS site, nitracline depth varied in a small range of 50-70 $\mathrm{m}$ throughout the year at SEATS (Tseng et al., 2005, 2007). However, the MLD deepened significantly during winter (Fig. 1), and it was comparable to the nitracline depth in the winter, but shallower than the nitracline in the rest of the year (Tseng et al., 2005, 2007). As a result, concentrations of nitrate + nitrite and phosphate in the surface mixed layer in winter were about an order of magnitude higher than in the summer which hovered around their respective detection limits of 0.03 and $0.01 \mu \mathrm{M}$. Consequently, picoplankton cells have greater fluorescence during winter and lower fluorescence during summer. The exceptional increase in picoeukaryote cellular fluorescence in summer 2005 likely reflects shifts in species. DuRand et al. (2001) observed inverse relationship between eukaryote cell concentration and cell size and fluorescence that suggests blooms of small cells in spring.

The changes in chlorophyll fluorescence with depth have been attributed to photoacclimation, as phytoplankton that grow in deeper water have higher pigment per cell to compensate for the decreased light levels (Olson et al., 1990; Campbell et al., 1997). Since nutrient conditions also can affect picoplankton cellular chlorophyll content (e.g., Liu et al., 1999a), the magnitude of the increase in chlorophyll fluorescence with depth must be determined by the combination of light and nutrient availability at depth. The increase of cellular chlorophyll fluorescence with depth was much lower in the SCS at SEATS than in the subtropical North Pacific gyre at ALOHA (Table 2). This can probably be explained by the shallower nitracline depth at SEATS (50-70 m, Tseng et al., $2005,2007)$ as compared to that at HOT (mean $120 \pm 20 \mathrm{~m}$, range $80-160 \mathrm{~m}$, Karl et al., 2003). Because the nitracline at SEATS was shallower than the euphotic layer depth $(75-90 \mathrm{~m}$, Tseng et al., 2005, 2007) throughout the year, photoaclimation may not need to be as strong for those cells that live in the layer where the top of the nitracline and the bottom of euphotic layer overlap. 
Table 2

Increase in relative cellular chlorophyll fluorescence (in the numbers of fold) between the low-fluorescence cells in the surface mixed layer and high-fluorescence cells in the deeper layer (mean $\pm 1 \mathrm{SD}, n=10$ for SEATS), at the HOT and SEATS sites

\begin{tabular}{llr}
\hline & HOT & SEATS \\
\hline Prochlorococcus & $35 \pm 14$ & $14 \pm 7$ \\
Synechococcus & $20 \pm 14$ & $10 \pm 7$ \\
Picoeukaryotes & $15 \pm 36$ & $5 \pm 2$ \\
\hline
\end{tabular}

Data for HOT are obtained from Campbell et al. (1997).

\subsection{Interannual variability}

Interannual variation of hydrographic conditions in the SCS is mostly associated with weakened circulation gyres and upwelling under weakened monsoons during El Niño (Chao et al., 1996). The SST anomaly in summer has been found to be well correlated with the equatorial SST anomalies in the preceding winter (Ose et al., 1997).

Comparing the two sampling years, 2001-2002 had higher SST than 2004-2005, but they both have similar MLD (Fig. 1). Consequently 2004-2005 had a stronger winter maximum in chl $a$ and higher total picophytoplankton and bacterial biomass (Fig. 3). The contribution of Prochlorococcus to total picophytoplankton biomass was higher, whereas the contribution of picoeukaryotes was lower in 2001-2002 than that in 2004-2005. These interannual differences are probably related to the El Niño and La Niña cycle. According to the Multivariate ENSO Index (MEI, http://www.cdc.noaa.gov/ ENSO/enso.mei_index.html), year 2001-2002 was during the transition from La Niña to El Niño conditions, whereas year 2004-2005 was in the middle of a weak El Niño period.

Studies have revealed that primary production in the eastern tropical Pacific was high during normal upwelling and low during El Niño, whereas the opposite was true for the North Pacific sub-tropical gyre (Barber and Chavez, 1983; Karl et al., 1995). In contrast, the contribution of Prochlorococcus to primary production increased in equatorial waters, but decreased in the sub-tropical gyre during the El Niño (Liu et al., 1999b). Since we have observed higher total autotrophic biomass, and a lower Prochlorococcus contribution in 2004-2005 (an El Niño year) than in 2001-2002, it is suggested that the northern SCS possesses a similar interannual pattern to the North Pacific sub-tropical gyre in phytoplankton biomass and primary productivity.
More data are needed to confirm the correlation between the ENSO cycle and phytoplankton community structure and productivity in the subtropical oceans, including large marginal seas like the SCS.

\section{Acknowledgments}

We are grateful to the officers and crew of the R/V Ocean Research I and III and Fishery Research I for their assistance in sampling. Special thanks are extended to T.D. Sue, H.-P. Lee, H.-S. Ong, W.-H. Lee, P.-W. Chiang, and L.-F. Hwang for collecting samples and to C.-W. Liao for assistance in flow cytometric analysis. We thank Professor G.-C. Gong of National Taiwan Ocean University for providing the access to their flow cytometry facility. We also wish to thank Dr. Paul Harrison and two anonymous reviewers for critical reading of the manuscript. This work was supported by the SouthEast Asian Time-series Study (SEATS; NSC 93-2119-M-002-032) from the National Science Council (Taiwan, Republic of China). This is contribution \#113 of the National Center for Ocean Research (NCOR), National Taiwan University (NTU), Taipei.

\section{References}

Barber, R.T., Chavez, F.P., 1983. Biological consequences of El Niño. Science 222, 1203-1210.

Bertilsson, S., Berglund, O., Karl, D.M., Chisholm, S.W., 2003. Elemental composition of marine Prochlorococcus and Synechococcus: implications for the ecological stoichiometry of the sea. Limnology and Oceanography 48, 1721-1731.

Blanchot, J., André, J.-M., Navarette, C., Neveux, J., Radenac, M.-H., 2001. Picophytoplankton in the equatorial Pacific: vertical distribution in the warm pool and in the high nutrient low chlorophyll conditions. Deep-Sea Research I 48, 297-314.

Bricaud, A., Allali, K., Morel, A., Marie, D., Veldhuis, M.J.W., Partensky, F., Vaulot, D., 1999. Divinyl chlorophyll $a$-specific absorption coefficients and absorption efficiency factors for Prochlorococcus marinus: kinetics of photoacclimation. Marine Ecology Progress Series 188, 21-32.

Cailliau, C., Claustre, H., Vidussi, F., Marie, D., Vaulot, D., 1996. Carbon biomass, and gross growth rates as estimated from ${ }^{14} \mathrm{C}$ pigment labeling, during photoacclimation in Prochlorococcus CCMP 1378. Marine Ecology Progress Series 145, 209-221.

Campbell, L., Nolla, H.A., Vaulot, D., 1994. The importance of Prochlorococcus to community structure in the central North Pacific Ocean. Limnology and Oceanography 39, 954-961.

Campbell, L., Liu, H., Nolla, H.A., Vaulot, D., 1997. Annual variability of picoplankton in the subtropical North Pacific Ocean at Station ALOHA. Deep-Sea Research I 44, 167-192. 
Cavender-Bares, K.K., Karl, D.M., Chisholm, S.W., 2001. Nutrient gradients in the western North Atlantic Ocean: relationship to microbial community structure and comparison to patterns in the Pacific Ocean. Deep-Sea Research I 48, 2373-2395.

Chao, S.Y., Shaw, P.T., Wu, S.Y., 1996. El Niño modulation of the South China Sea circulation. Progress in Oceanography 38, 51-93.

Chavez, F.P., Buck, K.R., Coale, K.H., Martin, J.H., DiTullio, G.R., Welschmeyer, N.A., Jacobson, A.C., Barber, R.T., 1991. Growth rates, grazing, sinking, and iron limitation of equatorial Pacific phytoplankton. Limnology and Oceanography 36, 1816-1833.

Claustre, H., Bricaud, A., Babin, M., Bruyant, F., Guillou, L., Le Gall, F., Marie, D., Partensky, F., 2002. Diel variations in Prochlorococcus optical properties. Limnology and Oceanography 47, 1637-1647.

Ducklow, H.W., Smith, D.C., Campbell, L., Landry, M.R., Quinby, H.L., Steward, G.F., Azam, F., 2001. Heterotrophic bacterioplankton in the Arabian Sea: basinwide response to year-round high primary productivity. Deep-Sea Research II 48, 1303-1323.

DuRand, M.D., Olson, R.J., Chisholm, S.W., 2001. Phytoplankton population dynamics at the Bermuda Atlantic Time-series station in the Sargasso Sea. Deep-Sea Research II 48, 1983-2003.

Fukuda, R., Ogawa, H., Nagata, T., Koike, I., 1998. Direct determination of carbon and nitrogen contents of natural bacterial assemblages in marine environments. Applied and Environmental Microbiology 64, 3352-3358.

Garrison, D.L., Gowing, M.M., Hughes, M.P., Campbell, L., Caron, D.A., Dennett, M.R., Shalapyonok, A., Olson, R.J., Landry, M.R., Brown, S.L., Liu, H.-B., Azam, F., Steward, G.F., Ducklow, H.W., Smith, D.C., 2000. Microbial food web structure in the Arabian Sea: a US JGOFS study. DeepSea Research II 47, 1387-1422.

Glover, H.E., Prézelin, B.B., Campbell, L., Campbell, L., Garside, C., 1988. A nitrate-dependent Synechococcus bloom in surface Sargasso Sea water. Nature 331, 161-163.

Heldal, M., Scanlan, D.J., Norland, S., Thingstad, F., Mann, N.H., 2003. Elemental composition of single cells of various strains of marine Prochlorococcus and Synechococcus using X-ray microanalysis. Limnology and Oceanography 48, 1732-1743.

Karl, D.M., Letelier, R., Hebel, D., Tupas, L., Dore, J., Christian, J., Winn, C., 1995. Ecosystem changes in the North Pacific subtropical gyre attributed to the 1991-1992 El Niño. Nature 373, 230-234.

Karl, D.M., Bates, N.R., Emerson, S., Harrison, P.J., Jeandel, C., Llinás, O., Liu, K.-K., Marty, J.-C., Michaels, A.F., Miquel, J.C., Neuer, S., Nojiri, Y., Wong, C.S., 2003. Temporal studies of biogeochemical processes determined from ocean time-series observations during the JGOFS era. In: Fasham, M.J.R. (Ed.), Ocean Biogeochemistry: The Role of the Ocean Carbon Cycle in Global Change. IGBP Book Series. Springer, New York, pp. 239-267.

Li, W.K.W., Subba Rao, D.V.W., Harrison, G., Smith, J.C., Cullen, J.J., Irwin, B., Platt, T., 1983. Autotrophic picoplankton in the tropical ocean. Science 219, 292-295.

Liu, A.K., Chang, Y.S., Hsu, M.K., Liang, N.K., 1998. Evolution of nonlinear internal waves in the East and South China Seas. Journal of Geophysical Research 103, 7995-8008.
Liu, H., Campbell, L., Landry, M.R., Nolla, H.A., Brown, S.L., Constantinou, J., 1998. Prochlorococcus and Synechococcus growth rates and contributions to production in the Arabian Sea during the 1995 Southwest and Northeast Monsoons. Deep-Sea Research II 45, 2327-2352.

Liu, H., Bidigare, R.R., Laws, E., Landry, M.R., Campbell, L., 1999a. Cell cycle and physiological characteristics of Synechococcus (WH7803) in chemostat culture. Marine Ecology Progress Series 189, 17-25.

Liu, H., Landry, M.R., Vaulot, D., Campbell, L., 1999b. Prochlorococcus growth rates in the central equatorial Pacific: an application of the $f_{\max }$ approach. Journal of Geophysical Research 104, 3391-3400.

Liu, H., Suzuki, K., Saito, H., 2004. Community structure and dynamics of phytoplankton in the western subarctic Pacific Ocean - a synthesis. Journal of Oceanography 60, 119-137.

Liu, K.-K., Chao, S.-Y., Shaw, P.-T., Gong, G.C., Chen, C.C., Tang, T.Y., 2001. Monsoon forced chlorophyll distribution and primary productivity in the South China Sea: observations and a numerical study. Deep-Sea Research I 49, 1387-1412.

Marie, D., Partensky, F., Jacquet, S., Vaulot, D., 1997. Enumeration and cell cycle analysis of natural population of marine picoplankton by flow cytometry using the nucleic acid stain SYBR Green I. Applied and Environmental Microbiology 63, 186-193.

Moore, L.R., Post, A.F., Rocap, G., Chisholm, S.W., 2002. Utilization of different nitrogen sources by the marine cyanobacteria, Prochlorococcus and Synechococcus. Limnology and Oceanography 47, 989-996.

Olson, R.J., Chisholm, S.W., Zettler, E.R., Altabet, M.A., Dusenberry, J.A., 1990. Spatial and temporal distributions of prochlorophyte picoplankton in the North Atlantic Ocean. Deep-Sea Research 37, 1033-1051.

Ose, T., Song, Y.K., Kitoh, A., 1997. Sea surface temperature in the South China Sea-an index for the Asian monsoon and ENSO system. Journal of Meteorological Society of Japan 75, 1091-1107.

Partensky, F., Blanchot, J., Vaulot, D., 1999. Differential distribution and ecology of Prochlorococcus and Synechococcus in oceanic waters: a review. In: Charpy, L., Larkum, A.W.D. (Eds.) Marine Cyanobacteria. Bulletin de l'Institut océanographique, Monaco, No. 19, pp. 457-475.

Rippka, R., Coursin, T., Hess, W., Lichtle, C., Scanlan, D.J., Palinska, K.A., Iteman, I., Partensky, F., Houmard, J., Herdman, M., 2000. Prochlorococcus marinus Chisholm et al. 1992 subsp. pastoris subsp. nov. strain PCC9511, the first axenic chlorophyll $\mathrm{a}(2) / \mathrm{b}(2)$-containing cyanobacterium (Oxyphotobacteria). International Journal of Systematic and Evolutionary Microbiology 50, 1833-1847.

Shalapyonok, A., Olson, R.J., Shalapyonok, L.S., 2001. Arabian Sea phytoplankton during Southwest and Northeast Monsoons 1995: composition, size structure and biomass from individual cell properties measured by flow cytometry. DeepSea Research II 48, 1231-1261.

Shaw, P.-T., Chao, S.-Y., 1994. Surface circulation in the South China Sea. Deep-Sea Research I 41, 1663-1683.

Strickland, J.D.H., Parsons, T.R., 1984. A Practical Handbook of Seawater Analysis, third ed. Queen's Printer, Ottawa, $311 \mathrm{pp}$.

Suzuki, K., Minami, C., Liu, H., Saino, T., 2002. Temporal and spatial patterns of chemotaxonomic algal pigments in the 
subarctic Pacific and the Bering Sea during the early summer of 1999. Deep-Sea Research II 49, 5685-5704.

Troussellier, M., Courties, C., Zettelmaier, S., 1995. Flow cytometric analysis of coastal lagoon bacterioplankton and picophytoplankton: fixation and storage effects. Estuarine, Coastal and Shelf Science 40, 621-633.

Tseng, C.-M., Wong, G.T.F., Lin, I.-I., Wu, C.-R., Liu, K.-K., 2005. A unique seasonal pattern in phytoplankton biomass in low-latitude waters in the South China Sea. Geophysical Research Letter 32, L08608.

Tseng, C.-M., Wong, G.T.F., Chou, W.-C., Lee, B.-S., Sheu, D.-D., Liu, K.-K., 2007. Temporal variations in the carbonate system in the upper layer at the SEATS station. Deep-Sea Research II, this issue.

Vaulot, D., 1989. CYTOPC: processing software for flow cytometric data. Signal and Noise 2, 8 .

Winn, C.D., Campbell, L., Christian, J.R., Letelier, R.M., Hebel, D.V., Dore, J.E., Fujieki, L., Karl, D.M., 1995. Seasonal variability in the phytoplankton community of the North
Pacific Subtropical Gyre. Global Biogeochemical cycles 9 (4), 605-620.

Wong, G.T.F., Ku, T.-L., Mulholland, M., Tseng, C.-M., Wang, D.-P., 2007a. The SouthEast Asian Time-series Study (SEATS) and the biogeochemistry of the South China Sea - An Overview. Deep-Sea Research II, this issue.

Wong, G.T.F., Tseng, C.M., Wen, L.S., Chung, S.W., $2007 \mathrm{~b}$. Nutrient dynamics and nitrate anomaly at the SEATS Station. Deep-Sea Research II, this issue.

Zubkov, M.V., Sleigh, M.A., Tarran, G.A., Burkill, P.H., Leakey, R.J.G., 1998. Picoplanktonic community structure on an Atlantic transect from $50^{\circ} \mathrm{N}$ to $50^{\circ} \mathrm{S}$. Deep-Sea Research I 45, 1339-1355.

Zubkov, M.V., Fuchs, B.M., Tarran, G.A., Burkill, P.H., Amann, R., 2003. High rate of uptake of organic nitrogen compounds by Prochlorococcus cyanobacteria as a key to their dominance in oligotrophic oceanic waters. Applied and Environmental Microbiology 69, 1299-1304. 